\title{
Use of Metal-mechanics Waste as an Addition in the Production of an Ecological Concrete
}

\author{
Johnny Alor ${ }^{1, a}$, Juan Alfaro ${ }^{1}$, José Rodríguez ${ }^{1}$ and Carlos Eyzaguirre \\ 1Ingeniería Civil, Universidad Peruana de Ciencias Aplicadas, Lima, Perú
}

\begin{abstract}
Currently, buildings are on the rise, which causes significant environmental pollution due to the lack of controlled landfills to deposit solid construction wast; an alternative solution is to recycle this waste produced by the construction and or demolition of concrete elements structural, and use them as coarse aggregate in the manufacture of concrete. On the other hand, the metalworking industry uses iron and steel as primary inputs, which are the main components of industrial waste, with its generation sources being industrial plants and manufacturing workshops for small and medium enterprises; a solution to this problem is to use your waste as a fine aggregate in the production of concrete due to its good properties. These solution alternatives preserve natural resources and promote their sustainability. The research work developed focuses on the use of structural concrete and steel waste to reduce its amount of waste and it is proposed to add it to the concrete. The results show that the addition of steel chips in concrete compared to standard concrete results in reduced slump, increased unit weight and contributes to the improvement of compressive strength, tcylinder splitting tensile strength and flexural strength.
\end{abstract}

\section{Introduction}

The construction sector requires $40 \%$ of the total energy and $50 \%$ of the total natural resources for the development of its different activities [1]. Likewise, these activities in large cities have grown dramatically due to the increase in population, producing a greater demand for land and the need to have urban areas with large areas. This situation has generated an increase in the amount of solid construction waste, which leads to the existence of environmental problems that must be addressed by the municipalities and regional governments, through the control and distribution of land destined as landfills [2]. Due to the lack of these for construction, construction companies choose to dispose of their waste in nearby places to avoid higher expenses, which causes unpleasant impacts on the landscape, underground water and soil pollution, deforestation, erosion and a major food hazard to surrounding areas; As a solution, it is proposed to use recycled concrete aggregates from the demolition of structural elements in the manufacture of concrete to help preserve natural resources and promote their sustainability [3], as well as the development of sustainable construction. According to [2] that recycled

\footnotetext{
${ }^{a}$ Corresponding author: u201320615@upc.edu.pe
}

aggregates have a rougher texture than natural aggregates and this causes some changes in workability, even if recycled materials are pre-saturated, resulting in reduced workability due to the high rate of Form of recycled materials. The authors of [4] found that the content of hardened cement in the recycled aggregate is greater than in the natural aggregate, the water absorption of the recycled aggregate is greater, and its yield is lower. According to the studies of [5] a concrete with recycled aggregates has a minimum compressive strength of $76 \%$ compared to concrete with natural aggregates. The autor [6] indicates that the use of recycled aggregates produces a $25 \%$ reduction in compressive strength in a concrete with natural aggregates, while in the case of tensile strength the reduction value is $14 \%$. The autor [7], replacing $20 \%$ of the natural coarse aggregate with recycled coarse aggregate, obtains that the flexural strength decreases by $13 \%$.

It is known that steel is the main component of industrial solid waste and that steel chips are obtained from its waste, which are obtained mainly through the work of the lathe, molding accessories of varied geometries and the development of new elements. These are stored in bags for disposal or sale to companies dedicated to the smelting of 
this waste and can then be reused. A solution to this problem is to use them as a fine aggregate in the production of concrete because they have $0 \%$ absorption and a specific weight greater than the fine aggregate. In this sense, several authors propose steel chips, in our case called VA, as a replacement for the components of the concrete, after having studied the effect of the addition of VA on the properties of the concrete pattern. The autor [6] indicates that after 28 days of curing, there is an increase in tensile strength and compressive strength of 1.4 to 2.4 times and 1.1 to 1.3 times, respectively. The autor [8] comments that at the age of 28 days, compressive strength increases between $10-15 \%$ and tensile strength increases $10-18 \%$. The autor [9] indicates that both compressive strength and flexural strength increase after 28 days by $18 \%$ and $9 \%$ respectively.

To have a broader view of the benefits of steel in concrete and having not found information on steel chips, we consider it important, for its similar behavior with steel chips, to describe the incidence of steel fibers in the properties of steel. concrete. Thus, we have that [10] explains that steel fibers have become very popular in the last two decades and are used in particular because they increase the self-healing capacity of cracks, covering these spaces where $1.5 \%$ is sufficient to perform this action. The autor [11] explains that the key to increasing the strength of a high-strength concrete is to increase its resistance to cracking; This increase is related to the number and size of the original cracks, and to the control of the beginning and extent of these cracks. On the other hand, [12] obtains that the cylinder splitting compressive strength at 28 days of concrete with steel fibers is twice as high as that of conventional concrete. This author evaluates the 3-point flexural strength with $100 \times 100 \times 500 \mathrm{~mm}$ samples tested at 28 days and obtains that the concrete with steel fibers is $43 \%$ higher than conventional concrete. Similarly, [13] studies different percentages of steel fiber addition: $0.5 \%$, $1.0 \%, 1.5 \%$ and $2 \%$, finding a maximum value of compressive strength at 28 days for $1.5 \%$ representing $15 \%$ more compared to conventional concrete; from there, the resistance decreases by $2 \%$ for $2.0 \%$ fiber. The autor [14] conducts the study for the addition of $1 \%$ steel fiber, finding that the compressive strength at 91 days increases by $18 \%$ compared to a concrete without fibers.

From the extensive literature review carried out, they have not found joint work on waste from recycled aggregates and VA as a replacement for the natural fine aggregate in the concrete production. What does exist are separate works of these wastes in the preparation of concrete. That is why, in the present investigation, the combination of the recycled coarse aggregate and the VA is used as a replacement for the natural fine aggregate in the preparation of concrete. For this, the physical, chemical and mechanical properties of the aggregates are studied: sieve analysis, moisture content, specific weight, absorption and unit weight; the properties of fresh concrete: slump and unit weight; and the properties of hardened concrete: compressive strength, cylinder splitting tensile strength and flexural strength.

\section{Materials and methods}

\subsection{Materials}

The following materials were used for the development of the research: Cement Sol Portland Type I, its properties are validated in accordance with [15]; drinking water of the city of Lima; natural fine aggregate, modulus of fineness of 2.8; coarse recycled aggregate of structural elements with a maximum size of $3 / 4$ "; Steel shavings with a maximum diameter of $0.3 \mathrm{~cm}$, obtained from an automotive company. A sample of the steel chips used in the investigation can be seen in Figure 1.

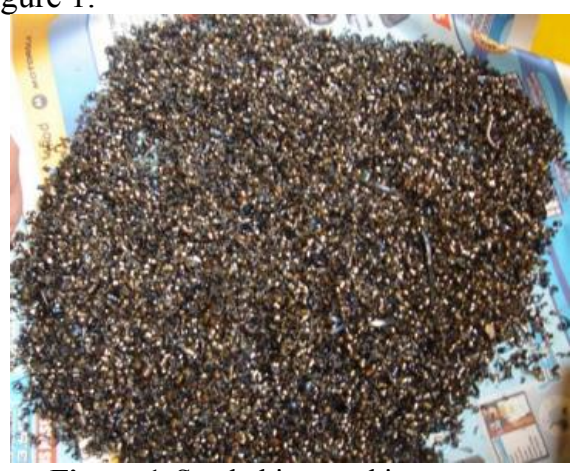

Figure 1. Steel chips used in concrete.

\subsection{Mix design}

The elaborated mix designs were made based on the procedure developed by [16] for a resistance of 21 MPA with an a / c ratio of 0.50. A sample of standard concrete used as a reference was designed, 3 designs were made with additions of VA at $8 \%, 10 \%$ and $12 \%$ respectively, then a comparison of its physical properties with respect to the standard concrete was made. Table 1 shows a summary of the test pieces used for the different tests performed and Table 2 details the materials used in the dosing of concrete mixtures.

Table 1. Test tubes used in the tests.

\begin{tabular}{|c|c|c|c|c|}
\hline \multirow{4}{*}{ Test type } & Code & Age & Quantity & $\begin{array}{c}\text { Dimension } \\
(\mathbf{c m})\end{array}$ \\
\hline \multirow{4}{*}{$\begin{array}{c}\text { Compressive } \\
\text { strength }\end{array}$} & VA-0 & $7,14,21$ y 28 & 12 & 15 x 30 \\
\cline { 2 - 5 } & VA-10 & $7,14,21$ y 28 & 12 & 15 x 30 \\
\cline { 2 - 5 } & VA-12 & $7,14,21$ y 28 & 12 & 15 x 30 \\
\hline \multirow{2}{*}{$\begin{array}{c}\text { Cylinder splitting } \\
\text { tensile strength }\end{array}$} & VA-0 & $7,14,21$ y 28 & 4 & 12 x 30 \\
\cline { 2 - 5 } & VA-8 & $7,14,21$ y 28 & 4 & 10 x 20 \\
\hline
\end{tabular}




\begin{tabular}{|c|c|c|c|c|}
\hline & VA-10 & $7,14,21$ у 28 & 4 & $10 \times 20$ \\
\hline & VA-12 & $7,14,21$ у 28 & 4 & $10 \times 20$ \\
\hline \multirow{4}{*}{ Flexural strength } & VA-0 & $7,14,21$ у 28 & 4 & $15 \times 15 \times 50$ \\
\hline & VA-8 & $7,14,21$ y 28 & 4 & $15 \times 15 \times 50$ \\
\hline & VA-10 & $7,14,21$ у 28 & 4 & $15 \times 15 \times 50$ \\
\hline & VA-12 & $7,14,21$ y 28 & 4 & $15 \times 15 \times 50$ \\
\hline
\end{tabular}

Table 2. Materials by $\mathrm{m}^{3}$ concrete mix

\begin{tabular}{|c|c|c|c|c|}
\hline \multirow{2}{*}{ Materials } & $\begin{array}{c}\text { Sample } \\
\text { Pattern }\end{array}$ & $\begin{array}{c}\mathbf{8 \%} \\
\text { Chips }\end{array}$ & $\begin{array}{c}\mathbf{1 0 \%} \\
\text { Chips }\end{array}$ & $\begin{array}{c}\mathbf{1 2 \%} \\
\text { Chips }\end{array}$ \\
\cline { 2 - 5 } & $\begin{array}{c}\text { Weight } \\
\text { (Kg) }\end{array}$ & $\begin{array}{c}\text { Weight } \\
\text { (Kg) }\end{array}$ & $\begin{array}{c}\text { Weight } \\
\text { (Kg) }\end{array}$ & $\begin{array}{c}\text { Weight } \\
\text { (Kg) }\end{array}$ \\
\hline Air & 0 & 0 & 0 & 0 \\
\hline Water & 226.72 & 226.72 & 226.72 & 226.72 \\
\hline Cement & 386.15 & 386.15 & 386.15 & 386.15 \\
\hline Recycled coarse ag. & 972.78 & 972.78 & 972.78 & 972.78 \\
\hline Natural fine ag. & 677.41 & 614.45 & 601.11 & 587.78 \\
\hline Chip & - & 102.53 & 128.17 & 153.82 \\
\hline Total & 2262.93 & 2302.48 & 2314.77 & 2327.06 \\
\hline
\end{tabular}

\subsection{Tests}

The present work has been developed in the Laboratory of Concrete Technology of the UPC-Monterrico, the tests of characterization of aggregates are shown in Table 3 and the tests of the standard concrete and concrete with VA in fresh and hardened state are shown in the Table 4.

Table 3. Aggregate tests.

\begin{tabular}{|c|c|}
\hline Test type & Methods \\
\hline \multirow{2}{*}{ Sieve analysis of fine and coarse aggregate } & NTP $400.012[26]$ \\
\hline & ASTM C-136 [27] \\
\hline \multirow{2}{*}{$\begin{array}{l}\text { Total evaporable moisture content of } \\
\text { aggregates by drying }\end{array}$} & NTP $339.185[42]$ \\
\hline & ASTM C-566 [29] \\
\hline \multirow{2}{*}{$\begin{array}{c}\text { Specific gravity and absorption of fine } \\
\text { aggregate }\end{array}$} & NTP $400.022[30]$ \\
\hline & ASTM C-128 [31] \\
\hline \multirow{2}{*}{$\begin{array}{c}\text { Specific gravity and absorption of coarse } \\
\text { aggregate }\end{array}$} & NTP 400.021 [32] \\
\hline & ASTM C-127 [33] \\
\hline \multirow{2}{*}{ Unit Weight } & NTP 400.017 [34] \\
\hline & ASTM C-29 [35] \\
\hline
\end{tabular}

Table 4. Concrete tests.

\begin{tabular}{|c|c|c|}
\hline Concrete Tests & Steel chip (\%) & Methods \\
\hline \multicolumn{3}{|c|}{ Fresh Concrete Test } \\
\hline Slump & $0,8,10,12$ & $\begin{array}{c}\text { NTP 339.035 [36] } \\
\text { ASTM C-143 [37] }\end{array}$ \\
\hline
\end{tabular}

\begin{tabular}{|c|c|c|} 
Unit Weight & $0,8,10,12$ & $\begin{array}{c}\text { NTP 339.046 [38] } \\
\text { ASTM C-138 [39] }\end{array}$ \\
\hline \multicolumn{2}{|c|}{ Hardened Concrete Test } \\
\hline Compressive strength & $0,8,10,12$ & $\begin{array}{c}\text { NTP 330.034 [40] } \\
\text { ATM C-39 [41] }\end{array}$ \\
\hline $\begin{array}{c}\text { Cylinder splitting tensile } \\
\text { strength }\end{array}$ & $0,8,10,12$ & $\begin{array}{c}\text { NTP 339.084 [42] } \\
\text { ASTM C-496 43] }\end{array}$ \\
\hline Flexural strength & $0,8,10,12$ & $\begin{array}{c}\text { NTP 339.079 [44] } \\
\text { ASTM C-78 [45] }\end{array}$ \\
\hline
\end{tabular}

\section{Results}

\subsection{Aggregate tests}

Table 5 shows the results for the tests of the aggregates used. The recycled coarse aggregate has its unit weights and specific gravity lower than the conventional aggregate, and the moisture and absorption content have values greater than a conventional aggregate. In the case of the natural fine aggregate, the values are within those established in [18]. In the case of steel chips, their specific weight is much higher than the conventional aggregate.

\subsection{Test in fresh concrete}

\subsubsection{Slump}

Figure 2 shows the influence of the percentage of steel chips on the slump, it shows that the slump decreases as the addition of steel chips is increased, obtaining 1.7 inches of slump for $8 \% \mathrm{VA}$ for an addition of $12 \%$ the value of 1.2 inches being the decrease of $29.41 \%$.

Table 5. Aggregate tests.

\begin{tabular}{|c|c|c|c|}
\hline Properties & $\begin{array}{c}\text { Recycled } \\
\text { coarse } \\
\text { aggregate }\end{array}$ & $\begin{array}{c}\text { Natural } \\
\text { fine } \\
\text { aggregate }\end{array}$ & $\begin{array}{c}\text { Steel } \\
\text { chips }\end{array}$ \\
\hline TMN (inches) & 1 & - & - \\
\hline Fineness module & - & 2.8 & - \\
\hline Moisture content $(\%)$ & 2.23 & 1.58 & - \\
\hline Specific weight $\left(\mathrm{kg} / \mathrm{m}^{3}\right)$ & 2329 & 2622 & 5040 \\
\hline Absorption $(\%)$ & 5.736 & 1.638 & - \\
\hline Compacted unit weight $\left(\mathrm{kg} / \mathrm{m}^{3}\right)$ & 1420 & 1800 & - \\
\hline
\end{tabular}




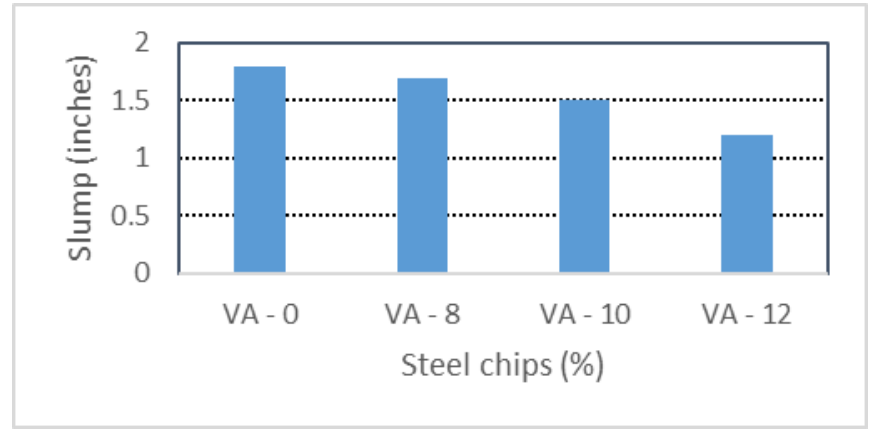

Figure 2. Influence of the percentage of VA on Slump.

\subsubsection{Unit weight}

Figure 3 shows the incidence of the percentage of steel chips on the unit weight of the concrete. The results indicate that the unit weight increases when the percentage of VA is increased, obtaining a value of $2394.08 \mathrm{~kg} / \mathrm{m}^{3}$ for $8 \%$ of VA and for the addition of $12 \%$ of VA a value of $2439.60 \mathrm{~kg} / \mathrm{m}^{3}$, the increase being of $1.90 \%$.

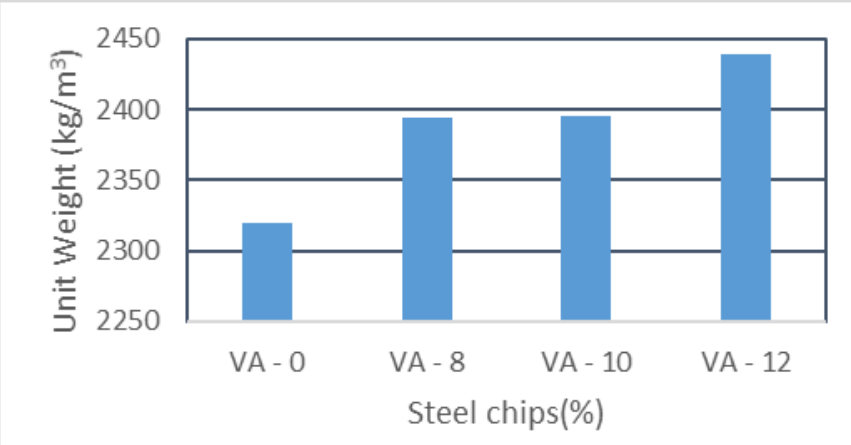

Figure 3. Influence of the percentage of VA on the unit weight.

\subsection{Tests in hardened concrete}

\subsubsection{Compressive strength}

The influence of the test age on the compressive strength for different percentages of VA is shown in Figure 4. In view of the results, it can be indicated that the compressive strength increases as the percentage of VA increases from $0 \%$ to $10 \%$ and from there decreases to the value of $12 \%$. The maximum resistance value reached at 28 days is $37.74 \mathrm{MPA}$ and represents a $22.37 \%$ increase with respect to the standard concrete and the minimum value of 32.21 MPA representing a percentage of $4.45 \%$ increase with respect to the standard concrete.

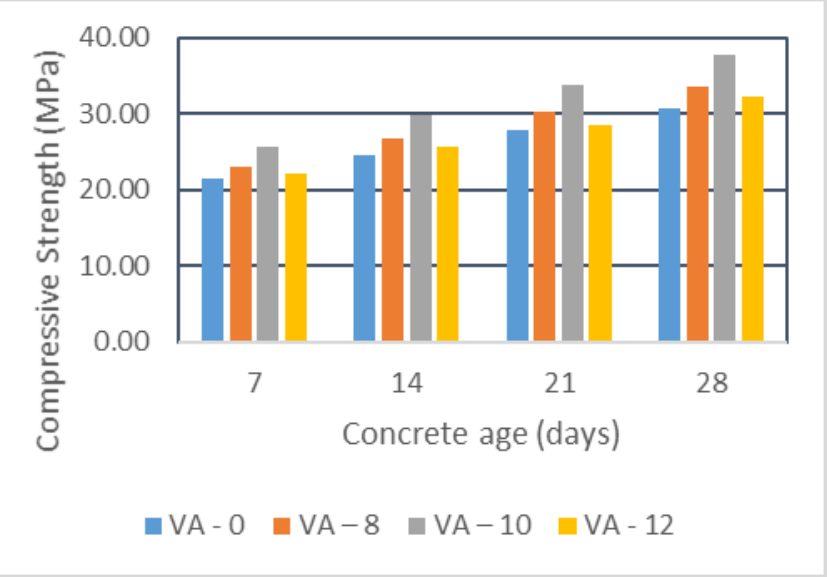

Figure 4. Influence of the test age on the compressive strength.

\subsubsection{Cylinder splitting tensile strength}

The influence of the test age on cylinder splitting tensile strength for different percentages of VA is shown in Figure 5. According to the results, it can be indicated that the tensile strength increases with the test age, obtaining a maximum resistance value at 28 days of $3.04 \mathrm{MPA}$ for $10 \% \mathrm{VA}$, representing $43.39 \%$; from this value there is a decrease of $18.09 \%$ corresponding to the value of $2.49 \mathrm{MPa}$ for $12 \%$ of VA.

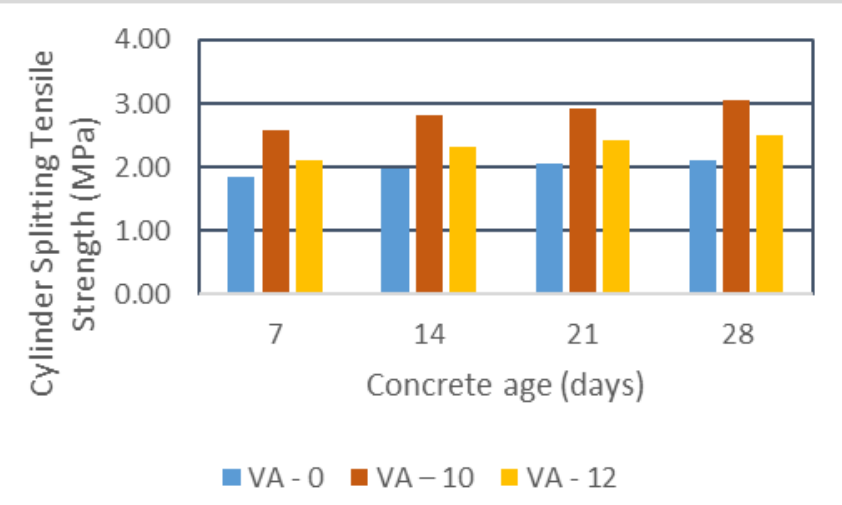

Figure 5. Influence of the test age on cylinder splitting tensile strength.

\subsubsection{Flexural strength}

The influence of the test age on the flexural strength with load in the center of the section for different percentages of VA is shown in Figure 6 from the results, it can be indicated that the flexural strength increases with the test age , reaching a maximum resistance value at 28 days of $5.51 \mathrm{MPa}$ for a $10 \% \mathrm{VA}$ representing a value of $21.63 \%$; from this value there is a decrease of $8.89 \%$ corresponding to the value of $5.02 \mathrm{MPa}$ for $12 \%$ of VA. 


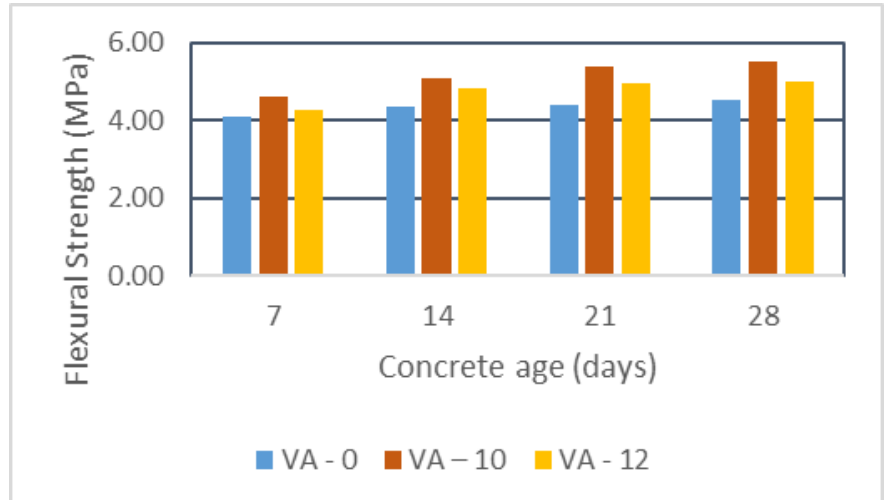

Figure 6. Influence of the test age on the flexural strength with load in the center of the concrete section.

\section{Analysis}

\section{1. $\quad$ Aggregate tests}

In work [19] conducts studies with the recycled coarse aggregate used in the preparation of a concrete and obtains values like section III.A. In the case of the specific weight it finds the value of $2280 \mathrm{~kg} / \mathrm{m} 3$, for the apparent density it obtains $1310 \mathrm{~kg} / \mathrm{m} 3$ and $5.8 \%$ for the Absorption.

In [20], states that when old concrete is crushed, a certain amount of mortar from the original concrete remains attached to the stone particles in the recycled aggregates. This bonded mortar makes recycled aggregates present different properties than natural ones that are reflected in an increase in water absorption, lower density, lower resistance, lower hardness and fragmentation resistance.

\subsection{Fresh concrete tests}

\subsubsection{Slump}

In work [21] conducted tests with a concrete with natural aggregates and steel chip additions. Their results show a trend like that indicated in section 3.2.1, so we have that the percentage of slump decrease is $8 \%$ when going from $10 \%$ to $20 \%$ of VA.

In work [7] explains that the reduction in slump is because the absorption of crushed concrete is greater than that of coarse aggregates. Therefore, the higher the percentage of aggregate of recycled concrete, the higher the percentage of absorption, the lower the fall. In [21] explains that this trend could be due to the heterogeneity and angular shapes of the steel chip particles, which lead to a lower fluidity of the mixtures.

\subsubsection{Unit weight}

In work [21] studies the unit weight of concrete mixtures with $10 \%, 15 \%$ and $20 \%$ steel chips and finds an increase of
$0.81 \%, 1.24 \%$ and $2.04 \%$, with respect to the unit weight of the standard sample.

In [9], indicates that this trend can be attributed to the fact that the specific gravity of steel chips is approximately $42.8 \%$ greater than the specific gravity of the fine aggregate and that the greater the addition of chips the greater the weight is concrete unit.

\subsection{Hardened concrete tests}

\subsubsection{Compressive strenght}

In work [21] conducts a study with $10 \%, 15 \%$ and $20 \%$ addition of VA in the concrete and obtains a behavior like that indicated in section 3.3.1. their results indicate that after 28 days of curing their concrete samples with $20 \%$ steel chips reach a compression resistance of 51.64 MPA which represents a $17.4 \%$ increase in reference to their standard sample. However, after 14 days of curing, a slight delay in the hydration of the cement was observed in comparison with the reference mixture, which resulted in a slight decrease in compressive strength of the mixtures with additions of steel chips.

In [22] explains that this trend may be due to the high density and strength of steel chips. On the other hand, [9] pointed out that at high VA contents, the reduction of concrete compactness causes a reduction in its compressive strength, however, it also observes a decrease in resistance. In this regard, [23] explains that this may be because the accumulation of iron residues in the cement particles forms a low penetration pseudomorph layer which causes a decrease in resistance.

\subsubsection{Cylinder splitting tensile strength}

In work [24] conducted different concrete tests at the ages of 7, 14 and 28 days using natural aggregates and steel chips with additions of $15 \%, 30 \%$ and $60 \%$ and obtained a similar trend to section 3.3.2. The author indicates that the cylinder splitting tensile strength of concrete specimens with VA increases with the increase in the percentage of chips in all curing periods. After 28 days of curing it obtains a maximum strength of 3.11 MPA with an addition of $60 \%$ steel chips, which represents $43.98 \%$ with respect to the standard sample.

In [9] explains that at small percentages, the chips increase the strength of the reinforced concrete by introducing some ductility in the post-fault behavior, and the fibers continue to support traction through the macro cracks; for high contents, the reduction of concrete compactness causes a reduction in its cylinder splitting tensile strength.

\subsubsection{Flexural strenght}

In work [21] conducted concrete trials at ages 3, 7, 14 and 28 days using natural aggregates and additions of 10\%, 15\% 
and $20 \%$ steel chips, obtaining a trend similar to section 3.3.3. The results indicate that after 28 days the concrete samples with $20 \%$ steel chips reach a resistance of 7.54 MPA which represents a $27.68 \%$ increase in reference to the standard sample. However, at 14 days a slight decrease in resistance is observed.

In [25] explains that this trend of increase occurs because metal chips are granulated in small sizes, which contributes to the VA being compatible in the concrete mix and improving their properties, however, it also observes a decrease in the resistance. In work [13] can attribute this to the accumulation of iron particles that prevent water penetration, with the consequent delay in cement hydration.

\section{Conclusions}

-The reuse of construction waste and VA help reduce the environmental impact that these wastes produce and contribute to sustainable construction.

-The coarse aggregate recycled because of its stone composition with mortar has a higher absorption percentage than a natural aggregate.

-The use of VA reduces the consistency of the concrete mixture, which is reflected in the lower slump values by increasing the percentage of VA.

-The use of VA in concrete with recycled coarse aggregate produces an increase in compressive strength, cylinder splitting tensile strength, and flexural strength.

-The addition of an optimal percentage of VA as a replacement for the fine aggregate in the mix design allows a greater resistance of the standard design.

\section{References}

1. Meyer, C. El enverdecimiento de la industria del hormigon. Cemento, Hormigon, 601 - 605, 2008.

2. Eckert, M. Mitigation of the negative efects of recycled aggregate water absorption in concrete technology. Construction and Building Materials 133:416-424, 2017.

3. Yong, P. Utilization of Recycled Aggregate as Coarse Aggregate in Concrete. UNIMAS E-Journal of Civil Engieneering, 1-6, 2009.

4. Gongbing Yuea, Qiuyi Lib, Jianlin Luo and Yuanxin Guod. Influence of Quality and Replacement Rate of Recycled Coarse Aggregate on the Frost Resistance of Recycled Concrete, 2019.

5. Frondistou-Yannas S. Waste concrete as aggregate for new concrete. ACI Materials, 74, pp. 373 - 376, 1997.

6. Qasarawi H, Shalabi F, Asi I. Use of low $\mathrm{CaO}$ unprocessed steel slag in concrete as fine aggregate, 2009.

7. Malek Batayneh, Iqbal Marie, Ibrahim Asi. Use of selected waste materials in concrete mixes, 2007.

8. Al-Jabri KS, Hisada M, Al-Oraimi SK, Al-Saidy AH. Copper slag as sand replacement for high performance concrete, 2009.
9. Said Djebali, Youcef Bouafia, Said Larbi, Ali Bilek. Mechanical Behavior of Steel-Chips-Reinforced Concrete, 2013.

10. Koda, M. "Selfhealing capability of fiber reinforced cementitious composites", Construction Materials through Science and Technology, Hong Kong, 2013.

11. Handong Yan, Wei Sun, Huisu Chen. The effect of silica fume and steel fiber on the dynamic mechanical performance of high-strength concrete, 1999.

12. R.V. Balendran, F.P. Zhou, A. Nadeem, A.Y.T. Leung. Influence of steel fibres on strength and ductility of normal and lightweight high strength concrete, 2001.

13. P. Song, S. Hwang. Mechanical properties of highstrength steel fiber-reinforced concrete, 2004.

14. V. Afroughsabet, T. Ozbakkaloglu. Mechanical and durability properties of high-strength concrete containing steel and polypropylene fibers, 2015.

15. NTP 334.009:2016, Cementos. Cemento Pórtland. Requisitos. Modificación Técnica 1. $1^{\mathrm{a}}$ Edición. Inacal, Lima 2017.

16. Amercian Concrete Institute. Standard Practice for selecting proportions for normal Heavyweight, and Mass Concrete (ACI -211). 1997

17. NTP 339.033:2015 Concreto. Práctica normalizada para la elaboración y curado de especímenes de concreto en campo. $4^{\mathrm{a}}$ Edición. Inacal, Lima 2016.

18. NTP 400.037:2018 Agregados. Agregados para concreto. Requisitos. $4^{\text {a }}$ Edición. Inacal, Lima 2018.

19. H. Qasrawi, I. Marie and H. Tantawi. Use of recycled concrete rubbles as coarse aggregate in concrete, 2012.

20. Bahareh Hadavand, Reza Imaninasab. Assessing the infuence of construction and demolition waste materials on workability and mechanical properties of concrete using statistical analysis, 2018.

21. Zainab Z. Ismail, Enas A. AL-Hashmi. Reuse of waste iron as a partial replacement of sand in concrete, 2008.

22. Demirboga, R., Gu1, R. Production of high strength concrete by use of industrial by-products. Building and Environment 41, 1124-1127, 2006.

23. Rai, A., Prabakar, J., Raju, C.B., Morchalle, R.K. Metallurgical slag as a component in blended cement. Construction and Building Materials 16, 489-494, 2002.

24. Laxmi Kanta Saha, Vikash Kumar, Mathew Varghese and Anjan Saha. Experimental Study on Properties of Concrete by Partial Replacement of Fine Aggregates with Waste Steel Chips, 2018.

25. Murali, G., Vardhan, C.M., Prabu, R.,Khan and Suresh, T., Experimental Investigation of Fibre Reinforced Concrete Using Waste Materials, 2012.

26. NTP 400.012:2013 Agregados. Análisis granulométrico del agregado fino, grueso y global. $3^{\mathrm{a}}$ Edición. Inacal, Lima 2018.

27. ASTM C136. Standard Test Method for Sieve Analysis of Fine and Coarse Aggregates. ASTM International, 2014.

28. NTP 339.185 :2013, Agregados. Método de ensayo normalizado para contenido de humedad total 
evaporable de agregados por secado. $2^{\text {a }}$ Edición. Inacal, Lima 2018.

29. ASTM C566. Standard Test Method for Total Evaporable Moisture Content of Aggregate by Drying. ASTM International, 2019.

30. NTP 400.022:2013, Agregados. Método de ensayo normalizado para la densidad, la densidad relativa (peso específico) y absorción del agregado fino. 3a Edición. Inacal, Lima 2018.

31. ASTM C128. Standard Test Method for Relative Density (Specific Gravity) and Absorption of Fine Aggregate. ASTM International, 2015.

32. NTP 400.021:2013; Agregados. Método de ensayo normalizado para la densidad, la densidad relativa (peso específico) y absorción del agregado grueso. 3a Edición. Inacal, Lima 2018.

33. ASTM C127. Standard Test Method for Relative Density (Specific Gravity) and Absorption of Coarse Aggregate. ASTM International, 2015.

34. NTP 400.017:2011, Agregados. Método de ensayo normalizado para determinar la masa por unidad de volumen o densidad ("Peso Unitario") y los vacíos en los agregados. 3a. Edición. Inacal, Lima 2016.

35. ASTM C29. Standard Test Method for Bulk Density ("Unit Weight") and Voids in Aggregate. ASTM International, 2017.

36. NTP 339.035:2015, Concreto. Método de ensayo para la medición del asentamiento del concreto de Cemento Portland. 4a. Edición. Inacal, Lima 2015.

37. ASTM C143. Standard Test Method for Slump of Hydraulic-Cement Concrete. ASTM International, 2015.

38. NTP 339.046:2008, Concreto. Método de ensayo para determinar la densidad (peso unitario), rendimiento y contenido de aire (método gravimétrico) del concreto. $2^{\text {a }}$ Edición. Inacal, Lima 2018.

39. ASTM C138. Standard Test Method for Density (Unit Weight), Yield, and Air Content (Gravimetric) of Concrete. ASTM International, 2017.

40. NTP 330.034:2015, Concreto. Método de ensayo normalizado para la determinación de la resistencia a la compresión del concreto en muestras cilíndricas. $4^{\mathrm{a}}$ Edición. Inacal, Lima 2015.

41. ASTM C39. Standard Test Method for Compressive Strength of Cylindrical Concrete Specimens. ASTM International, 2018.

42. NTP 339.084:2012, Concreto. Método de ensayo normalizado para la determinación de la resistencia a tracción simple del concreto, por compresión diametral de una probeta cilíndrica. Inacal, Lima 2018.

43. ASTM C496. Standard Test Method for Splitting Tensile Strength of Cylindrical Concrete Specimens. ASTM International, 2017.

44. NTP 339.079:2012, Concreto. Método de ensayo para determinar la resistencia a la flexión del concreto en vigas simplemente apoyadas con cargas en el centro del tramo. $3^{\mathrm{a}}$ Edición. . Inacal, Lima 2017.
45. ASTM C78. Standard Test Method for Flexural Strength of Concrete (Using Simple Beam with ThirdPoint Loading). ASTM International, 2018. 